\title{
Assessment of Physicochemical Characteristics of Mini-Ezi Stream in Elele-Alimini, Emohua Local Government Area of Rivers State, Nigeria
}

\author{
Okey-Wokeh Chidinma Georginia ${ }^{1}$, Obunwo Charles $\mathrm{C}^{2}$. and Boisa Ndokiari ${ }^{3}$ \\ Department of Chemistry, Rivers State University, Port Harcourt, P.M.B 5080 \\ Nkpolu-Orowurukwo, Nigeria
}

\begin{abstract}
Mini-Ezi Stream is one major aquatic ecosystem in Elele-Alimini that receives arrays of wastes generated from agricultural farms, residential homes, fecal discharges and other products of anthropogenic activities along the stream course. Samples of water from the stream were collected to assess the physicochemical characteristics during both dry and wet seasons. Thirteen physicochemical parameters were analyzed. pH, Electrical Conductivity (EC), Total Dissolved Solids (TDS), Temperature and Turbidity were determined in situ, while Bicarbonate, Dissolved Oxygen (DO), Biochemical Oxygen Demand (BOD), Total Hardness ( $\mathrm{TH})$, Chloride $(\mathrm{Cl})$, Phosphate $\left(\mathrm{PO}_{4}{ }^{3-}\right)$, Nitrate $\left(\mathrm{NO}_{3}{ }^{-}\right)$and Sulphate $\left(\mathrm{SO}_{4}{ }^{2-}\right)$ were determined using standard analytical procedures in the laboratory. The result revealed that Temperature, EC, TDS and Bicarbonate levels showed significant differences $(p<0.05)$, with the dry season recording higher mean values than the wet season. On the other hand, $\mathrm{NO}_{3}^{-}, \mathrm{PO}_{4}{ }^{3-}$, $\mathrm{Cl}$ and $\mathrm{SO}_{4}^{2-}$ recorded higher mean values in wet season which may be due to runoff from land mass. The result showed that all the physicochemical parameters analyzed in water from Mini-Ezi Stream were within the national and international set standards except for turbidity that was above the set standard. Therefore, this study can serve as baseline information for the periodic monitoring of water quality of the stream.
\end{abstract}

Keywords: Assessment, Mini-Ezi Stream, Physicochemical Characteristics, Surface Water, Water Quality.

\section{INTRODUCTION}

Water is one of the most valuable and indispensable gifts of nature that has positively affected human life in diverse ways [1].There are various sources of water, which include stream, river, well, borehole, spring, lakes and ocean [2]. One major source of water that provides man with number of services such as water for domestic uses, agricultural, industrial, transportation and recreational purposes is the stream [3].This source of water also serves as recipient of waste, which may contaminate or impair the quality of water [4]. A number of characteristics - chemical, physical, biological and radiological define the quality of water [5]. It is therefore important to evaluate the quality of stream water, since it can be the main pathway for the dissemination of toxic chemicals and pathogenic microorganisms [6].

Mini-Ezi Stream is an important aquatic ecosystem in Elele- Alimini that serves as a source of drinking water particularly for farmers during the farming season. The stream also serves as source of water for washing of clothes, cars for motorists that ply through the Alimini/Okini-Ali road, fishing and other purposes for natives. The strategic location of Mini-Ezi Stream makes the aquatic ecosystem to receive large amount of wastes and runoff from residential, agricultural farm and other arrays of anthropogenic activities within Elele-Alimini and its environs. In spite of all the anthropogenic activities around this stream, there is still paucity of information on the chemical studies of the Mini-Ezi water body. It is therefore pertinent to monitor the surface water of Mini-Ezi Stream in order to ascertain the physicochemical characteristics, as the result obtained will help to know the level, the source and the risk of pollution involved for both human and aquatic organisms. It is against this backdrop that the study on assessment of the physicochemical characteristics of Mini-Ezi Stream in Elele-Alimini was carried out 


\section{MATERIALS AND METHODS}

\subsection{Description of Study Area}

The study was carried out in Mini-Ezi Stream in Elele Alimini, Emohua Local Government Area of Rivers State. Mini-Ezi Stream is the major aquatic ecosystem in Alimini, taking its source from Orashi River and connecting to New Calabar River. This river flows down to Ogbodu-Isiokpo where it is joined by a smaller tributary river that rises at Aluu and then empties into some creek and lagoon bordering the Atlantic Ocean. Mini-Ezi Stream is a fresh and non-tidal aquatic ecosystem lying between Latitude $5^{0} 45^{1} \mathrm{~N}$ and Longitude $7^{0} 60^{1} \mathrm{E}$.

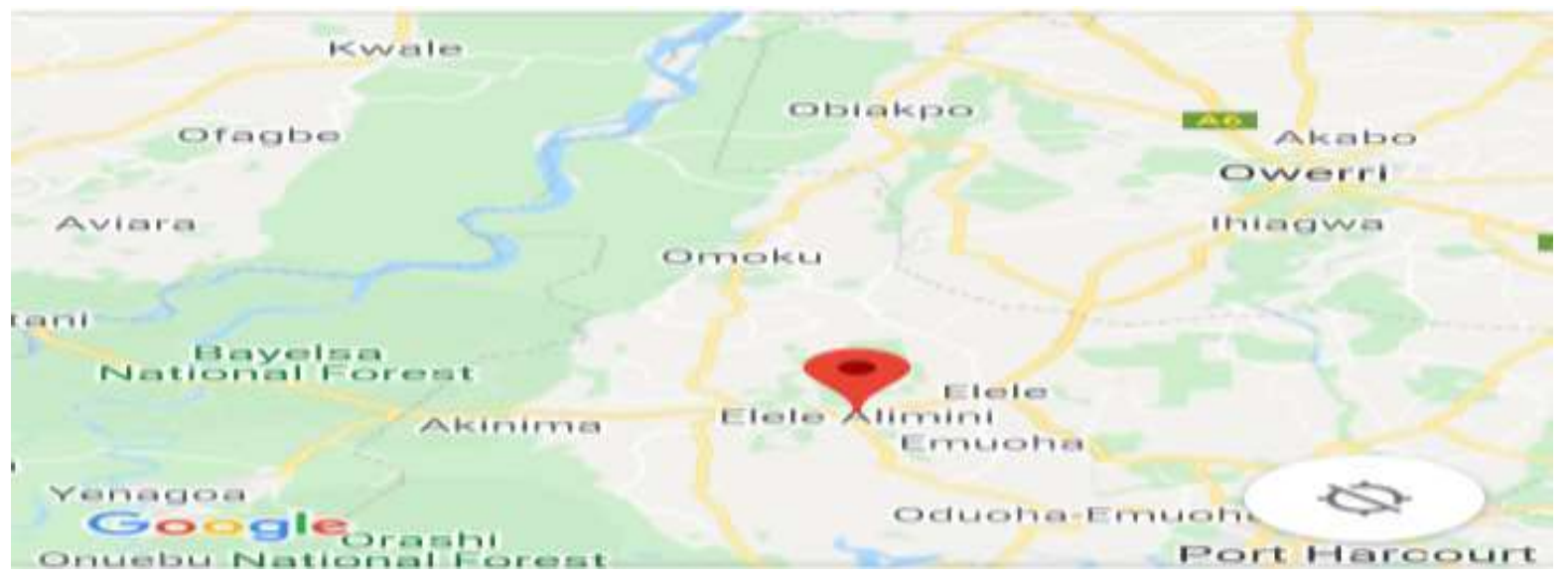

Fig 1: Map of the Study Area Showing Sampling Location (Source: Google Map)

\subsection{Sample Collection}

Water samples were collected at Mini-Ezi Stream at three different locations, on monthly basis for the period of six months, covering peak of dry (December to February) and peak of wet (June to August) seasons. At each station, water samples were collected for Dissolved Oxygen (DO) and Biochemical Oxygen Demand (BOD) analysis, as well as other physicochemical parameters. In situ determination of some parameters was done, while water samples collected for other physiochemical parameters were stored in ice-chest, prior to analysis.

\subsection{Sample Analysis}

The analysis of physiochemical parameters in water obtained from Mini-Ezi was done using standard analytical procedure. Water $\mathrm{pH}$, temperature, turbidity, TDS and electrical conductivity were measured in situ. Water $\mathrm{pH}$ was determined with the aid of electric digital $\mathrm{pH}$ meter, (Jenway Ltd, model 350. $\mathrm{pH}$ meter). Temperature was measured with the aid of liquid-in-glass thermometer, turbidity with the aid of turbidity meter (Turner designs Aquafluor 8000-001) while electrical conductivity and TDS were determined with the aid of conductivity meter (Mettler Toledo M-226 conductivity meter). BOD $_{5}$ was fixed in situ in amber bottle and determined in the laboratory according to Winkler's method. The determination of total hardness (TH) was done by EDTA Complexometric tritration method using Eriochrome Black-T as indicator, while chloride $\left(\mathrm{Cl}^{-}\right)$was determined by Argentometric titration method. Phosphates were determined by stannous chloride method. Nitrate was determined by Brucine Method while Sulphate was determined by Turbidimetric method.

\subsection{Statistical Analysis}

All parameters were statistically analyzed using Excel Spreadsheet.

\section{RESULTS AND DISCUSSION}

The results of physiochemical parameters obtained from analysis and their comparison with national and international standard are shown in Table 1. The table presents the mean, standard deviation and ranges of all the parameters during dry and wet seasons.

Table 1: Mean of Physiochemical Parameters of Mini-Ezi Stream in both Dry and Wet Seasons. 
International Journal of Advances in Scientific Research and Engineering (ijasre), Vol 6 (1), January-2020

\begin{tabular}{|c|c|c|c|c|c|c|c|}
\hline \multirow[b]{2}{*}{$\begin{array}{l}\text { PARAMETER } \\
\text { (units) }\end{array}$} & \multicolumn{2}{|l|}{ DRY } & \multicolumn{2}{|l|}{ WET } & \multicolumn{2}{|l|}{ LIMITS } & \multirow[b]{2}{*}{$\begin{array}{l}\text { T-TEST } \\
\text { VALUE }\end{array}$} \\
\hline & MEAN & RANGE & MEAN & RANGE & WHO & SON & \\
\hline pH & $7.489 \pm 0.32$ & $6.9-7.9$ & $7.46 \pm 0.21$ & $7.2-7.8$ & $6.5-8.5$ & $6.5-8.5$ & 0.411 \\
\hline Temp. $\left({ }^{\circ} \mathrm{C}\right)$ & $28.06 \pm 0.80$ & $26.9-29.1$ & $23.79 \pm 0.38$ & $23.1-24.4$ & $<40.0$ & $<40.0$ & 0.000 \\
\hline $\mathrm{EC}(\mu \mathrm{s} / \mathrm{cm})$ & $267.8 \pm 23.57$ & $227-229$ & $185.89 \pm 32.6$ & 134-234 & 1000 & 1000 & 0.000 \\
\hline Turb. (NTU) & $13.50 \pm 7.04$ & $4.3-24.16$ & $20.45 \pm 2.10$ & $18.16-24$ & 5.0 & 5.0 & 0.014 \\
\hline TDS (mg/L) & $145.37 \pm 30.4$ & 115-199.3 & $172.44 \pm 26.03$ & $138-200$ & 1000 & 500 & 0.030 \\
\hline $\mathrm{HCO}_{3}^{-}(\mathrm{mg} / \mathrm{L})$ & $2.79 \pm 0.55$ & $2.21-3.7$ & $1.27 \pm 0.47$ & $0.64-2.1$ & 100 & 100 & 0.000 \\
\hline $\mathrm{Cl}^{-}(\mathrm{mg} / \mathrm{L})$ & $1.79 \pm 0.37$ & $1.24-2.37$ & $2.77 \pm 1.24$ & $1.94-4.3$ & 250 & 100 & 0.003 \\
\hline TH (mg/L) & $19.48 \pm 1.5$ & $16.7-21.8$ & $15.49 \pm 3.26$ & $10.4-20.11$ & $100-500$ & 100 & 0.001 \\
\hline DO $(\mathrm{mg} / \mathrm{L})$ & $5.16 \pm 0.31$ & $4.8-5.8$ & $5.45 \pm 0.40$ & $4.9-5.96$ & $5.0-7.0$ & 7.0 & 0.061 \\
\hline BOD $(\mathrm{mg} / \mathrm{L})$ & $2.78 \pm 0.36$ & $2.2-3.3$ & $1.77 \pm 0.36$ & $1.3-2.4$ & $2.0-5.0$ & 5.0 & 0.000 \\
\hline $\mathrm{NO}_{3}^{-}(\mathrm{mg} / \mathrm{L})$ & $2.0 \pm 0.45$ & $1.32-2.8$ & $4.71 \pm 2.85$ & $1.77-10.7$ & 50 & 10 & 0.015 \\
\hline $\mathrm{PO}_{4}{ }^{3-}(\mathrm{mg} / \mathrm{L})$ & $0.196 \pm 0.12$ & $0.07-0.41$ & $3.44 \pm 1.52$ & $1.84-6.2$ & 6.5 & 5.0 & 0.000 \\
\hline $\mathrm{SO}_{4}{ }^{2-}(\mathrm{mg} / \mathrm{L})$ & $1.28 \pm 0.23$ & $1.07-1.81$ & $2.58 \pm 1.13$ & $1.02-3.82$ & 100 & 100 & 0.008 \\
\hline
\end{tabular}

3.1. pH: The test on water $\mathrm{pH}$ was done to determine the acidity and alkalinity nature of the river water [7]. The values of $\mathrm{pH}$ obtained in this study as shown in Table 1, ranged from 7.20 to 7.80 with a mean value of $7.46 \pm 0.21$ in wet season and 6.90 to 7.90 with a mean value $7.49 \pm 0.32$ in dry season. The mean $\mathrm{pH}$ showed no significant difference $(\mathrm{p}>0.05)$ between dry and wet seasons. The stream water was slightly alkaline, which is similar to the report of [8] from River Jibam in Plateau State. This could be attributed to the presence of bicarbonates and biological degradation of waste in the soil which may have been washed into the stream by rainfall [9]. The $\mathrm{pH}$ values obtained in this study were within national and international standard of 6.5 to 8.5 [10] [11].The slight alkaline nature observed in Mini-Ezi Stream is common and typical of aquatic ecosystem not badly impacted [12].

3.2. TEMPERATURE: The temperature of stream water is one of the physical properties for dynamics of aquatic environment, because it interferes in the metabolic processes of organisms, influences the reproduction and increases the rate of degradation of organic matter [2]. From Table 1, the values of temperature obtained in Mini-Ezi Stream ranged from 23.10 to $24.40{ }^{\circ} \mathrm{C}$ with a mean value of $23.79 \pm 0.38$ in wet season and 26.90 to $29.10{ }^{\circ} \mathrm{C}$ with a mean value of $28.06 \pm 0.80$ in dry season. The mean values showed significant difference $(\mathrm{p}<0.05)$ between dry and wet seasons, with dry season recording higher values than the wet. This observation is typical of most tropical river surface water [13]. The values of water temperature recorded in the study falls within $<40{ }^{\circ} \mathrm{C}$ set standard by World Health Organization [10] and Standard Organization of Nigeria [11].

3.3. ELECTRICAL CONDUCTIVITY: The electrical conductivity (EC) of stream water is a useful indicator of total salt content which could be influenced by sewage discharges and other anthropogenic activities along the river bank [14]. The result obtained from the study revealed that EC values ranged from 134.0 to $234.0 \mu \mathrm{s} / \mathrm{cm}$, with a mean value of $185.89 \pm 32.61$ in wet season and 227.0 to $299.0 \mu \mathrm{s} / \mathrm{cm}$ with a mean value of $267.80 \pm 23.58$ in dry season. There was visible significant difference $(p<0.05)$, with the mean values obtained in dry season recording higher EC values than wet season (see Table 1). These are in consonance with the observation of [15] in Elele Alimini stream, but lower than the range of values reported by [5] in OtamiriOche River in Etche. The slightly higher conductivity values recorded in this stream could be attributed to discharges from the surrounding land mass and domestic sources along the stream bank, which contain lots of solutes and dissolved compounds ([16]. The EC values are lower in wet season due to dilution and flushing of mineral components but higher in dry season due to evaporation and concentration factor [17]. The mean values were far below $1000 \mu \mathrm{s} / \mathrm{cm}$ permissible limit set by national and international organizations.

3.4. TURBIDITY: This is the measure of disorderliness caused by suspended and fine insoluble particles in water body [18] [17]. The values of turbidity as shown in Table 1 , ranged from 18.16 to $24.0 \mathrm{NTU}$ with a mean of $20.45 \pm 2.10$ in wet season and 4.30 to $24.16 \mathrm{NTU}$ with a mean value of $13.50 \pm 7.04$ in dry season. The mean values showed significant difference $(\mathrm{p}<0.05)$, with wet season recording higher mean value than dry season. This could be attributed to runoff carrying sediments from the nearby areas and mixing up with non-living matter like silt and sand at the bottom of the stream during wet season [14]. The mean values were above $5.0 \mathrm{NTU}$ set as standard by WHO and SON. 
International Journal of Advances in Scientific Research and Engineering (ijasre), Vol 6 (1), January-2020

3.5. TOTAL DISSOLVED SOLIDS (TDS): It is the measure of inorganic salts and other substances dissolved in aquatic ecosystem [19]. The values of TDS obtained in this study ranged from 138.0 to $200.0 \mathrm{mg} / \mathrm{L}$ with a mean value of $172.44 \pm 26.03$ in wet season and 115.0 to $199.30 \mathrm{mg} / \mathrm{L}$ with a mean value of $145.37 \pm 30.41$ in dry season (see Table 1). The mean values showed significant difference $(\mathrm{p}<0.05)$, with wet season recording a higher mean value than dry season. This is consistent with the observations of [13] reported to be a common phenomenon in most Nigerian inland waters due to more runoffs and allochthonous materials washed into the river ecosystem during the wet season. The mean values of TDS in this study are lower than the $1000 \mathrm{mg} / \mathrm{L}$ recommended value by [10] for drinking water and $500 \mathrm{mg} / \mathrm{L}$ [11] guideline for water quality in Nigeria.

3.6. BICARBONATE: Bicarbonate is one vital physiochemical parameter of river water that has the ability to enhance conductivity and water alkalinity [20]. From Table 1, the result obtained in this study revealed that the values of bicarbonate ranged from 0.64 to $2.10 \mathrm{mg} / \mathrm{L}$ with a mean value of $1.27 \pm 0.47$ in wet season and 2.21 to $3.70 \mathrm{mg} / \mathrm{L}$ with a mean value of $2.79 \pm$ 0.55 in dry season. The mean values showed seasonal significant difference $(\mathrm{p}<0.05)$ with dry season recording higher mean value. The range of values recorded in this study is consistent with the observation of [21] in water samples from river system in Delta State. The presence of bicarbonates in this river water may be attributed to degradation of domestic and fecal waste discharged to the river, which may have influenced $\mathrm{pH}$ and EC concentration [22]. The mean values were far below $100 \mathrm{mg} / \mathrm{L}$ permissible limit set by [10] which indicated that the river surface water is soft.

3.7. CHLORIDE ( $\left.\mathbf{C l}^{-}\right)$: Chloride is an important physiochemical parameter of the aquatic ecosystem that indicates presence of organic waste in water when it is beyond desirable limits in inland water [23]. The values of $\mathrm{Cl}^{-}$obtained in this study from Table 1 , ranged from 1.94 to $4.30 \mathrm{mg} / \mathrm{L}$ with a mean value of $2.77 \pm 0.81$ in wet season and 1.24 to $2.37 \mathrm{mg} / \mathrm{L}$ with a mean value of 1.79 \pm 0.39 in dry season. The mean values showed significant difference $(\mathrm{p}<0.05)$ with the mean value in wet season recording higher than that of dry season. This result is in line with the findings of [13] [5]. The values recorded in both wet and dry season were far below $250 \mathrm{mg} / \mathrm{L}$ set as [10] and $100 \mathrm{mg} / \mathrm{L}$ by [11] standard, which is indicative that the stream is completely freshwater in nature.

3.8. TOTAL HARDNESS (TH): Total Hardness is one of the physicochemical parameters of water used to describe the effect of dissolved minerals, particularly Calcium and Magnesium ions $\left(\mathrm{Ca}^{2+}\right.$ and $\left.\mathrm{Mg}^{2+}\right)$ which determine suitability of water for domestic and industrial purposes [24]. From Table 1, the values of TH obtained in Mini-Ezi Stream ranged from 10.40 to 20.11 $\mathrm{mg} / \mathrm{L}$ with a mean value of $15.49 \pm 3.26$ in wet season, and 16.70 to $21.80 \mathrm{mg} / \mathrm{L}$ with a mean value of $19.48 \pm 1.50$ in dry season. This is similar to the report of [8] in Jibam River. There was significant difference $(\mathrm{p}<0.05)$ with dry season recording higher mean value due to concentration factor than the wet season [17]. The values obtained in this study in both seasons were below $100-500 \mathrm{mg} / \mathrm{L}$ [10] and 100mg/L [11] permissible limits. The stream water is soft and so is usable for both bathing and washing of clothing.

3.9. DISSOLVED OXYGEN (DO): Dissolved oxygen in water is an important parameter that determines the quality of river water since it is required for aerobic and metabolic process of organisms in aquatic ecosystem as well as decomposition of organic matter [25]. From Table 1, the values of DO obtained in this study ranged from 4.90 to $5.96 \mathrm{mg} / \mathrm{L}$ with a mean value of $5.45 \pm$ 0.40 in wet season and 4.80 to $5.80 \mathrm{mg} / \mathrm{L}$ with a mean value of $5.16 \pm 0.31$ in dry season. There was no significant difference $(p>0.05)$ between the mean value recorded in wet and dry season, though the values recorded in wet season were higher than dry season. This is in consonance with the report of [17] who reported that higher values of DO in wet season was a general characteristics of tropical waters, since high temperature causes decrease in solubility of dissolved oxygen. The mean DO values recorded in this study is within the national and international standard of 5.0 to $7.0 \mathrm{mg} / \mathrm{L}$.

3.10. BIOCHEMICAL OXYGEN DEMAND (BOD): Biochemical oxygen demand is known as the oxygen required for microorganism to breakdown organic matter in the waste under aerobic conditions [26]. A low value of BOD in water is an indicator of good water quality [27]. The values of BOD obtained in this study ranged from 1.30 to $2.40 \mathrm{mg} / \mathrm{L}$ with a mean value of $1.77 \pm 0.36$ in wet season, and 2.20 to $3.30 \mathrm{mg} / \mathrm{L}$ with a mean value of $2.78 \pm 0.36$ in dry season (see Table 1). There was significant difference $(\mathrm{p}<0.05)$ with dry season recording higher mean value than wet season. This finding is similar to the observation of [15] in Elele-Alimini stream. The higher value of BOD in dry season could be attributed to the effect of higher temperature and putrefaction of substances deposited in the stream from surrounding environment [17]. The mean values obtained in both dry and wet season were within the 2.0 to $5.0 \mathrm{mg} / \mathrm{L}$ WHO standard for surface water.

3.11. NITRATE $\left(\mathrm{NO}_{3}{ }^{-}\right)$: Nitrate in water is a product of anthropogenic activities such as runoff from agricultural lands and discharge of household wastes, which indicates the presence of fully oxidized organic matter [24]. From Table 1, the values of nitrate in surface water of Mini-Ezi Stream ranged from 1.77 to $10.70 \mathrm{mg} / \mathrm{L}$ with a mean value of $4.71 \pm 2.88$ in wet season and 1.32 to $2.80 \mathrm{mg} / \mathrm{L}$ with a mean value of $2.00 \pm 0.45$ in dry season. There was significant difference $(\mathrm{p}<0.05)$ with wet season 
recording higher mean value than dry season. This could be attributed to runoff from waste and human defecation around the stream course [28]. The values recorded in this study are within $50 \mathrm{mg} / \mathrm{L} \mathrm{[10]} \mathrm{and} 10 \mathrm{mg} / \mathrm{L}$ [11] standard. Higher nitrate in water is indicative of pollution, which causes blue baby syndrome disease in human [23].

3.12. PHOSPHATE $\left(\mathrm{PO}_{4}{ }^{3-}\right)$ : Phosphate is an essential nutrient that serves as an indicator of anthropogenic biological pollution, responsible for eutrophic condition in aquatic ecosystem [12]. The result of this study revealed in Table 1, that the values of phosphate ranged from 1.84 to $6.20 \mathrm{mg} / \mathrm{L}$ with a mean value of $3.44 \pm 1.52$ in wet season and 0.07 to $0.41 \mathrm{mg} / \mathrm{L}$ with a mean value of $0.196 \pm 0.12$ in dry season. The mean values showed significant difference $(p<0.05)$, with higher values observed in wet season. The observation in this study conforms to the report of [29] in Mini-Weja stream. The values recorded in both wet and dry season were below $5 \mathrm{mg} / \mathrm{L}$ guideline by [11] and $6.5 \mathrm{mg} / \mathrm{L}$ permissible limit for surface water by [10].The low values of phosphate in this aquatic ecosystem is a common feature of tropical freshwater bodies [16] [30].

3.13. SULPHATE $\left(\mathrm{SO}_{4}{ }^{2-}\right)$ : Sulphate ions occur in natural water and in higher concentration, contributes to permanent hardness of water [31]. From Table 1, the values of sulphate in Mini-Ezi Stream ranged from 1.02 to $3.82 \mathrm{mg} / \mathrm{L}$ with a mean value of 2.58 \pm 1.13 in wet season and 1.07 to $1.80 \mathrm{mg} / \mathrm{L}$ with a mean value of $1.28 \pm 0.23$ in dry season. The mean values showed significant difference $(\mathrm{p}<0.05)$, with the wet season recording higher mean values. This finding is in conformity with the observation of [12]. The result of sulphate in this study is far below $100 \mathrm{mg} / \mathrm{L}$ recommended for surface water by [10] and do not show any characteristics of eutrophication, thereby confirming the reports by [15] that sulphate, phosphate and nitrate levels control algal growth and eutrophication in river ecosystem.

\section{CONCLUSION}

The results obtained in the assessment of physiochemical characteristics of Mini-Ezi Stream reveal that apart from turbidity, all other parameters were within the set standards by national and international organizations. This shows that the stream water is still fit for domestic use. Therefore, this result can serve as baseline information for the periodic monitoring of Mini-Ezi Stream.

\section{ACKNOWLEDGEMENT}

I want to posthumously acknowledge late Mrs I. Orlu of Chemistry Laboratory, Department of Chemistry, Rivers State University, for her laboratory support and assistance during my PhD research analysis, where this paper was extracted.

\section{REFERENCES}

1. O.S. Olatunji, and O. Osibanjo, "Determination of Selected Heavy Metals in Inland Fresh Water of Lower River Niger Drainage in North Central Nigeria'. African Journal of Environmental Science and Technology.vol. 6, issue 10. 403-408, 2012.

2. M. Tadesse, D. Tsegaye and G. Girma, "Assessment of level of some physicochemical parameters and heavy metals of Rebu River in Oromia Region, Ethiopia'. Journal of Historical Archaeology \& Anthropological Sciences. vol.2, issue 3.146-150, 2018.

3. B.B. Otene and I.O Ukwe, "Evaluation of heavy metal accumulation in water and sediment from Elechi Creek, Port Harcourt, Nigeria'. International Journal of Geography and Environmental Management. Vol.4, issue 1: 1-8, 2018.

4. O.S. Edori, and F. Kpee, "Physiochemical and Heavy Metal assessment of water samples from boreholes near some Abattoirs in Port Harcourt, Rivers State, Nigeria’. American Chemical Science Journal vol.14, issue 3: 1-8, 2016.

5. B.M. Onyegeme-Okerenta, C. Obia, and M.O Wegwu, "Physiochemical properties of water quality of Imeh, Edegelem and Chokocho Communities located along Otammiri-Oche River in Etche Ethnic Nationality of Rivers State, Nigeria'. Journal of Applied Science and Environmental Management. Vol.20, No1, 113-119, 2016.

6.K.K. Vadde, J. Wang, L. Cao, T.Yuan, A.J. McCarthy, et al., “Assessment of water quality and identification of pollution risk locations inTiaoxi River (Taitu water shed) China”. Journal of Water Resources 10, 183, 2018.

7. A.I. Ezeribe, K.C. Oshieke and A. Jauro, "Physiochemical properties of well water samples from some villages in Nigeria with cases of stained and mottle teeth'. Science World Journal vol.1, issue 1, 2012. 
International Journal of Advances in Scientific Research and Engineering (ijasre), Vol 6 (1), January-2020

8. I.L. Dapam, E.G. Ibrahim and J.N Egula, “'Assessment of Physicochemical Parameters and Heavy Metal Speciation Study of Water and Bottom Sediments from River Jibam in Chip Districts of Pankshin Local Government Area, Plateau State, Nigeria'. Journal of Applied Chemistry.vol. 9, issue 11: 57-64, 2016.

9. L.T. Popoola, A.S. Yusuff and T.A. Aderibigbe, "Assessment of Natural groundwater physiochemical properties in major Industrial locations of Lagos Metropolis”. Appied Water Science, vol. 9, issue191, 2019.

10. WHO Chronicles 38, Guidelines for drinking water quality, F edition, 104-108, 2011.

11. Standard Organisation of Nigeria (SON). Nigerian Standard for Water Quality, Lagos, Nigeria, 2007.

12. M. Kidu, A. Gebrekidan, A. Hadera, and Y. Weldegebriel, “Assessment of Physiochemical Parameters of TSAEDAAGAM River in Mekelle City, Tigray, Ethiopia’. Bulletin of Chemical Society of Ethiopia, vol.29, issue 3 377-385, 2015.

13. S.O Ikhuoriah, and C.G. Oronsaye, “Assessment of physiochemical characteristics and heavy metal, of Ossiomo River, Ologbo- A Tributary of Benin River, Southern Nigeria', Journal of Applied Science and Environmental Management. Vol.20, issue 2: 472-481, 2016.

14.C.Y. Seng, T. Rath, S. Lim, C. Eav and K. Phan, “Assessment of physicochemical properties of the river water in Phnom penh and its suburban area". The bulletin of Cambodian Chemical society vol.9, No 1-2: 29-35, 2018.

15. B.B. Otene, and J.F. Alfred-Ockiya, “Assessment of water quality index (WQI) and suitability for consumption of EleleAlimini Stream, Port Harcourt', Global Scientific Journals vol.7, issue 2: 839-847, 2019.

16. R.F.N. Tony, D.H. Ogbuagu, T.E.Ebe, M.N Ezike, I.O. Egbuawa, et al., "'Investigation of Physiochemical Parameters and Plankton Biotopes in Ntawogba Creek, Diobu, Port Harcourt', Journal of Water Resources and Ocean Science. Vol.7, issue 3: 20-27, 2018.

17. C.C. Duru, U.I Daniel and J.N. Ogbulie, “Impacts of Organic Waste on Water Quality of Woji Creek in Port Harcourt, Nigeria'. Journal of Applied Science and Environmental Management. Vol. 22, issue 5, 625-630, 2018.

18. O.A.F. Wokoma, and K. Njoku, "Physical and chemical characteristics of the lower Sombreiro River, Niger Delta, Nigeria'. Applied Science report, vol. 20, No1: 11-16, 2017.

19. D. Berihum, and Y. Solomon, "Assessment of the Physicochemical and Heavy Metal Concentration from Effluents of Paint Industry in Addis Ababa, Ethiopia’'. International Journal of Waste Resource, vol. 7, 306, 2017.

20. P.K. Sadhana, “Geochemical parameters of water quality of Kara River, Hetauda Industrial Area, Central Nepel'”. Journal of institute of science and technology vol.20, issue 2:31-36, 2015.

21. A.N. Kaizer and S.A. Osakwe, " Physiochemical characteristics and heavy metal levels in water samples from Five River Systems in Delta State, Nigeria'. Journal of Applied Science and Environmental Management. Vol. 14, issue 1, 83-87, 2010.

22. J.K. Ebigwai, I.E Imedimfon, H.A. Bright, C. Olowu and Ekanem, "Physiochemical Parameter and Phytoplankton Assemblages Along Spatial and Temporal Gradients in Great Kwa River, Calabar, Nigeria', International Journal of Biological Chemistry vol.8, issue 1: 1-20, 2014

23. N. Gupta, K.K. Yadav, V. Kumar and D.Singh, “Assessment of physicochemical properties of Yamuna River in Agra City”. International Journal of Chemical Technology and Research. Vol. 1, 528-531, 2013.

24.S.O.Adewoye, A.O. Adewoye, O.A. Opasola and J.A Elegbede, “Physicochemical Parameters and Heavy Metal Analysis of Water Samples from Hand Dug Wells in Gambari, Ogbomosho, Oyo State', Journal of Environ. Sc. Toxico and Food Tech vol.5, issue 1: 22-30, 2013.

25. Y.A. El-Amier, M.A. Zahran, S.H. Al-Mamory, “Assessment of Physicochemical Characteristics of Sediments in Rosetta Branch , Egypt'”. Journal of Water Source and Protection. Vol.7, 1075-1086, 2015. 
International Journal of Advances in Scientific Research and Engineering (ijasre), Vol 6 (1), January-2020

26. O. Ogundele and G.O Mekuleyi, "Physicochemical properties and heavy metal concentration in waste water discharged from two industries in Agbara, Lagos State Nigeria'. International Research Journal of Public and Environmental Health. Vol.5, issue 3, 32-37, 2018.

27. U.M. Qureshimatva, R.R. Maverya, S.B Gamit, R.D. Patel and H.A Solanki, “'Determination of physicochemical parameters and water quality index (WQI) of Chanlodia Lake, Ahmedabad Gujarat, India', Journal of Environmental Anal Toxicology, vol.5, issue 4: 288, 2015.

28. A.A. Adesuyi, V.C. Nnodu, K.L Njoku and A. Jolaoso, "Nitrate and Phosphate pollution in surface water of Nwaja Creek, Port Harcourt, Niger Delta, Nigeria'. International Journal of Geology, Agriculture and Environmental Sciences. vol.3, issue 5: 14-20, 2015.

29. S.A. Braide, W.A. Izonfuo, P.U. Adiukwu, A.C. Chindah and C.C Obunwo, "Water quality of Mini-Weja stream , A swamp forest stream receiving non-point source waste discharges in Eastern Niger Delta, Nigeria', Scientia Africana vol.3, issue 1: 1-8, 2004.

30.A.C. Chindah and S.A. Braide, "The Physicochemical Quality and Phytoplankton Community of Tropical Waters: A Case of 4 Biotopes in the Lower Bonny River, Niger Delta, Nigeria'. Caderno de Pesquisa Ser.Bio.Santa cruz do sul. Vol.16, issue 2: 7-37, 2004.

31. A.D. Smitha and P. Shivashankar, "Physicochemical Analysis of the Freshwater at River Kapila Nanjangudu Industrial Area, Mysore India'. International Research Journal of Environmental Sciences. vol.2, issue 8, 59-65, 2013. 